\title{
Glutathione redox cycle in small intestinal mucosa and peripheral blood of pediatric celiac disease patients
}

\author{
VESNA STOJILJKOVIĆ ${ }^{1}$, SNEŽANA PEJIĆ ${ }^{1}$, JELENA KASAPOVIĆ ${ }^{1}$, LJUBICA GAVRILOVIĆ ${ }^{1}$, \\ STANIMIR STOJILJKOVIĆ ${ }^{2}$, DRAGAN NIKOLIĆ ${ }^{3,4}$ AND SNEŽANA B. PAJOVIĆ ${ }^{1}$ \\ ${ }^{1}$ Laboratory of Molecular Biology and Endocrinology, "Vinča" Institute of Nuclear Sciences, \\ University of Belgrade, P.O. Box 522, 11001 Belgrade, Serbia \\ ${ }^{2}$ Faculty of Sport and Physical Education, University of Belgrade, Blagoja Parovića 152, 11000 Belgrade, Serbia \\ ${ }^{3}$ Faculty of Medicine, University of Belgrade, Dr Subotića 9, 11000 Belgrade, Serbia \\ ${ }^{4}$ Institute for Endocrinology, Diabetes and Metabolic Diseases, Clinical Centre of Serbia, \\ Dr Subotića 13, 11000 Belgrade, Serbia
}

Manuscript received on March 23, 2011; accepted for publication on September 8, 2011.

\begin{abstract}
The celiac disease is an autoimmune gastrointestinal disorder caused by gluten from wheat, rye or barley. In genetically predisposed persons, gluten induces the immune-mediated inflammation of small intestinal mucosa. Histological lesions include intraepithelial lymphocytosis, crypt hypertrophy and villous atrophy, resulting in malabsorption of micro- and macronutrients. The only treatment for celiac patients is a permanent gluten-free diet (GFD). Reactive oxygen species (ROS) and oxidative stress are strongly associated with the celiac disease. Glutathione (GSH) is a main detoxifier of endogenous and exogenous ROS in the intestine. In order to explain the role of glutathione redox cycle in celiac patients, we examined the activities of GSHrelated antioxidant (AO) enzymes glutathione peroxidase (GPx) and glutathione reductase (GR), as well as the concentration of GSH in small intestinal biopsies and peripheral blood of children affected by the celiac disease. The concentration of lipid hydroperoxides $(\mathrm{LOOH})$ as markers of oxidative damage was measured in the same samples. The results clearly demonstrate a significant malfunction of GSH redox cycle with a concomitant decrease in the capacity to regenerate GSH and detoxify LOOH in celiac patients, even after several years of GFD. The oral administration of GSH and a diet rich in natural antioxidants, as well as appropriate dietary supplements, could be of great benefit to the patients.
\end{abstract}

Key words: antioxidant enzymes, celiac disease, glutathione, lipid peroxidation.

\section{INTRODUCTION}

Glutathione is a powerful antioxidant, antitoxin and enzyme-cofactor. It often reaches millimolar concentrations in the cell, which makes it one of the most important intracellular antioxidants

Correspondence to: Vesna Stojiljković

E-mail: vesnas@vinca.rs
(Masella et al. 2005). Glutathione is mostly present in cells in a reduced form (GSH). In a healthy cell, oxidized glutathione (glutathione disulfide, GSSG) rarely overcomes $10 \%$ of total glutathione pool (Kosower and Kosower 1978) and decreased GSH/ GSSG ratio is a good indication of oxidative stress (Hwang et al. 1992). GSH has a multiple function in the organism. GSH S-transferases (GST) use 
it as a cofactor in the detoxification of various endogenous and exogenous toxins. Gammaglutamyl transpeptidase uses GSH as a cofactor in transporting amino acids into cells. A group of enzymes known as GSH transhydrogenases uses GSH in a wide range of $-\mathrm{S}-\mathrm{S}-$ to $-\mathrm{S}-\mathrm{H}$ conversions. GSH also has an indispensable role in the AO defense. GSH redox cycle is a crucial protective mechanism against cell membrane damage by lipid peroxidation (LPO), a chain reaction in which polyunsaturated fatty acids (PUFA) in membrane lipids are being oxidized by ROS (Spiteller 2007, Liu et al. 2005). The antioxidant enzyme GPx uses GSH for reducing $\mathrm{LOOH}$ and hydrogen peroxide $\left(\mathrm{H}_{2} \mathrm{O}_{2}\right)$, while GR reduces GSSG with a simultaneous oxidation of nicotinamide adenine dinucleotide phosphate (NADPH). In addition to be a cofactor for GPx, GSH can directly react with free radicals and has an important role in regenerating active forms of other antioxidants due to its reduction potential.

The celiac disease is an autoimmune gastrointestinal disorder provoked by wheat gluten and related cereal proteins (from rye, barley and possibly oats). In genetically predisposed persons, gluten induces the immune-mediated inflammation of small intestinal mucosa. Histological lesions include intraepithelial lymphocytosis, crypt hypertrophy and villous atrophy, resulting in an inadequate absorption of micro- and macronutrients from the intestinal tract. The clinical presentation of the celiac disease is exceedingly heterogeneous and varies greatly with the age of the patients, duration and intensity of the disease and possible presence of extra intestinal disorders (Esteve et al. 2006). The classical gastrointestinal form of the disease, which is present mostly in infants and young children, is characterized by diarrhea, flatulence and abdominal pain, failure to thrive or weight loss (Fasano and Catassi 2005). In older children and adults, a variety of other clinical manifestations has been described, including the atypical or asymptomatic form (Dewar and Ciclitira 2005, Farrell and Kelly 2002, Murray 1999). The untreated celiac disease is associated with increased morbidity including various malignancies (Green et al. 2003). The only treatment for celiac patients is a permanent GFD, which usually rapidly solves gastrointestinal symptoms, while mucosal healing may prolong for months or years, especially in adult patients (Ryan and Kelleher 2000). GFD also prevents complications associated with the untreated celiac disease.

The activation of an immune cascade by gluten peptides leading to the inflammation of the intestinal mucosa is the main pathway of the pathogenesis of the celiac disease. However, direct cytotoxic effects of gluten should not be neglected. Several studies have shown that ROS and oxidative stress are strongly associated with the celiac disease (Dugas et al. 2003, Maiuri et al. 2003). In our previous papers we investigated the AO status of children affected by the celiac disease (Stojiljković et al. 2007, 2009). Since GSH is a main detoxifier of endogenous and exogenous ROS in intestine (LeGrand and Aw 2001), in this study we focused on the role of glutathione redox cycle in celiac patients.

\section{MATERIALS AND METHODS}

SUBJECTS

The study involved small intestinal biopsy specimens and peripheral blood samples from 33 children (19 girls and 14 boys; median age of 8 years; range of 1-15 years) affected by the celiac disease. The diagnosis of the disease was made at the University Children's Hospital, Belgrade, Serbia, according to the criteria of the European Society for Paediatric Gastroenterology, Hepatology and Nutrition (ESPGHN) (Walker-Smith 1990). Twenty children were diagnosed at the time of the investigation. All these children were making a gluten containing diet and had symptoms that are characteristic for the celiac disease, while the analysis of intestinal biopsy specimens revealed 
a typical villous atrophy (active group). In 13 children the diagnosis was made in early childhood and since then they have been subjected to GFD. At the time of sampling they were using GFD for 2-5 years, and the histopathologic examination of their intestinal biopsies showed a completely healed mucosa (GFD group). In addition, blood and intestinal biopsy samples from 29 children with various gastrointestinal symptoms (fatigue, chronic abdominal pain, diarrhea and weight loss), but with normal endoscopic, histopathologic and serologic results, were used as a control group.

The investigation has been approved by the Ethical Committee of the School of Medicine, University of Belgrade. The parents of all patients included in the study provided a written informed consent.

\section{SAMPLE PREPARATION}

From each patient, 6-8 proximal small intestinal biopsy specimens, as well as peripheral blood samples, were obtained. Some of the biopsies were used for histopathological analysis, while others were washed in ice-cold saline and frozen at $-70{ }^{\circ} \mathrm{C}$ for GPx, GR, GSH and LOOH assays. One biopsy specimen from each patient was kept on $-70{ }^{\circ} \mathrm{C}$ for the GSH assay, while others were thawed within a week and homogenized in 20 volumes of cold sucrose buffer $\mathrm{pH}$ 7.4. Homogenates were vortexed 3 times for 15 seconds and then kept at $-70{ }^{\circ} \mathrm{C}$. Thawed homogenates were centrifuged (Eppendorf centrifuge 5417R, Eppendorf-Netheler - Hinz GmbH, Hamburg, Germany) at $8600 \mathrm{~g}, 4^{\circ} \mathrm{C}$ for 10 minutes. Supernatants were stored at $-70^{\circ} \mathrm{C}$.

The blood samples were collected in the morning, in tubes containing lithium heparin as the anticoagulant. For the GPx, GR and $\mathrm{LOOH}$ assay, the blood was centrifuged at $1000 \mathrm{~g}, 4{ }^{\circ} \mathrm{C}$ for 15 minutes. The plasma was stored at $-70{ }^{\circ} \mathrm{C}$ for the $\mathrm{LOOH}$ assay, and the buffy coat was discarded. The red blood cells were washed three times in cold saline and then lysed in 20 packed-cell volumes of ice-cold water. Lysates were centrifuged at $8500 \mathrm{~g}$, $4{ }^{\circ} \mathrm{C}$ for 10 minutes to remove the blood cell stroma, and supernatants were stored at $-70^{\circ} \mathrm{C}$. For the GSH assay, the whole blood was frozen at $-70^{\circ} \mathrm{C}$.

ASSAYS

All assays were performed spectrophotometrically (Perkin Elmer Spectrophotometer, Lambda 25, Perkin Elmer Instruments, Norwalk, CT, USA). The specific enzyme activities of GPx and GR in blood were expressed as units per gram of hemoglobin $(\mathrm{U} / \mathrm{g} \mathrm{Hb})$, and in the intestinal mucosa as milliunits per milligram of protein $(\mathrm{mU} / \mathrm{mg})$. Concentrations of GSH and $\mathrm{LOOH}$ were expressed in micromoles per liter $(\mu \mathrm{mol} / \mathrm{L})$.

GPx assay. The GPx activity was determined by the Oxis Bioxytech ${ }^{\circledR}$ GPx-340 ${ }^{\mathrm{TM}}$ Assay (Oxis International, Inc., Portland, OR, USA). Upon the reduction of organic peroxide by GPx, GSSG is produced and its recycling to GSH by GR is accompanied by the oxidation of NADPH to NADP ${ }^{+}$. The rate of NADPH oxidation, followed by a decrease in absorbance at $340 \mathrm{~nm}$ as a function of time, is directly proportional to the GPx activity in the sample. One GPx-340 activity unit is defined as 1 $\mu$ mol of NADPH consumed per minute under the assay conditions.

GR assay. The activity of GR was measured by the Oxis Bioxytech ${ }^{\circledR}$ GR-340 ${ }^{\mathrm{TM}}$ Assay (Oxis International, Inc., Portland, OR, USA). The assay is based on the oxidation of NADPH to $\mathrm{NADP}^{+}$by GR from the sample. The rate of NADPH oxidation was determined by the rate of the decrease in absorbance at $340 \mathrm{~nm}$. One GR-340 unit is defined as $1 \mu \mathrm{mol}$ of NADPH oxidized per minute under the assay conditions.

GSH assay. The concentration of GSH was determined by the Oxis Bioxytech ${ }^{\circledR}$ GSH-420 ${ }^{\mathrm{TM}}$ Assay (Oxis International, Inc., Portland, OR, USA). For the GSH assay in intestinal biopsy samples, the 
thawed tissue was homogenized in 20 volumes of precipitating reagent (trichloroacetic acid), and homogenates were centrifuged at $3.000 \mathrm{~g}, 4{ }^{\circ} \mathrm{C}$ for 10 minutes. Supernatants were used for the assay. For the GSH assay in blood, the thawed blood was vortexed with three volumes of precipitating reagent at 10.000 $\mathrm{g}$, room temperature, for $5 \mathrm{~min}$, and supernatants were used for the assay. The method is based on the formation of a chromophoric thione. The reaction is performed in three steps. The sample was first buffered and treated with a reducing agent (tris (2-carboxyethyl)phosphine) to reduce any oxidized glutathione present in the sample. Then the chromogen (4-chloro-1-methyl-7-trifluoromethylquinolinium methylsulphate) was added, forming thioethers with all thiols in the sample. After the addition of a base to raise the $\mathrm{pH}$ over 13 , a $\beta$-elimination specific to the GSH-thioether results in the chromophoric thione. The absorbance at $420 \mathrm{~nm}$ is directly proportional to the GSH concentration.

LOOH assay. The concentration of $\mathrm{LOOH}$ was determined by the Oxis Bioxytech ${ }^{\circledR}$ LPO- $560^{\text {TM }}$ Assay (Oxis International, Inc., Portland, OR, USA). The assay is based on the oxidation of ferrous to ferric ions by LOOH from the sample under acidic conditions. Ferric ions bind with the indicator dye (xylenol orange), forming a stable coloured complex. The absorbance at $560 \mathrm{~nm}$ is directly proportional to the $\mathrm{LOOH}$ concentration. To eliminate the $\mathrm{H}_{2} \mathrm{O}_{2}$ interference, the samples were pre-treated with catalase.

\section{Statistics}

Differences among the groups were tested by analysis of variance. Comparisons among the patient groups were performed by Bonferroni post hoc test. Correlations among AO enzyme activities, GSH concentration and LOOH concentration were evaluated by Pearson's product moment correlation. A $P$ value lower than 0.05 was considered significant.

\section{RESULTS}

The activities of GPx and GR and the concentrations of GSH and LOOH in small intestinal mucosa (left) and peripheral blood (right) are represented in Fig. 1. The GPx activity varied significantly among the examined groups, both in mucosa $(\mathrm{F}=6.41$, $P<0.01)$ and erythrocytes $(\mathrm{F}=15.21, P<0.001)$. In the active group the GPx activity in the mucosa was reduced for $30 \%$ when compared to the control group $(P<0.01)$. The decrease in the GPx activity was found in erythrocytes as well, both in the active group, for about $35 \%(P<0.001)$, and the GFD group, for $20 \%(\mathrm{P}<0.05)$.
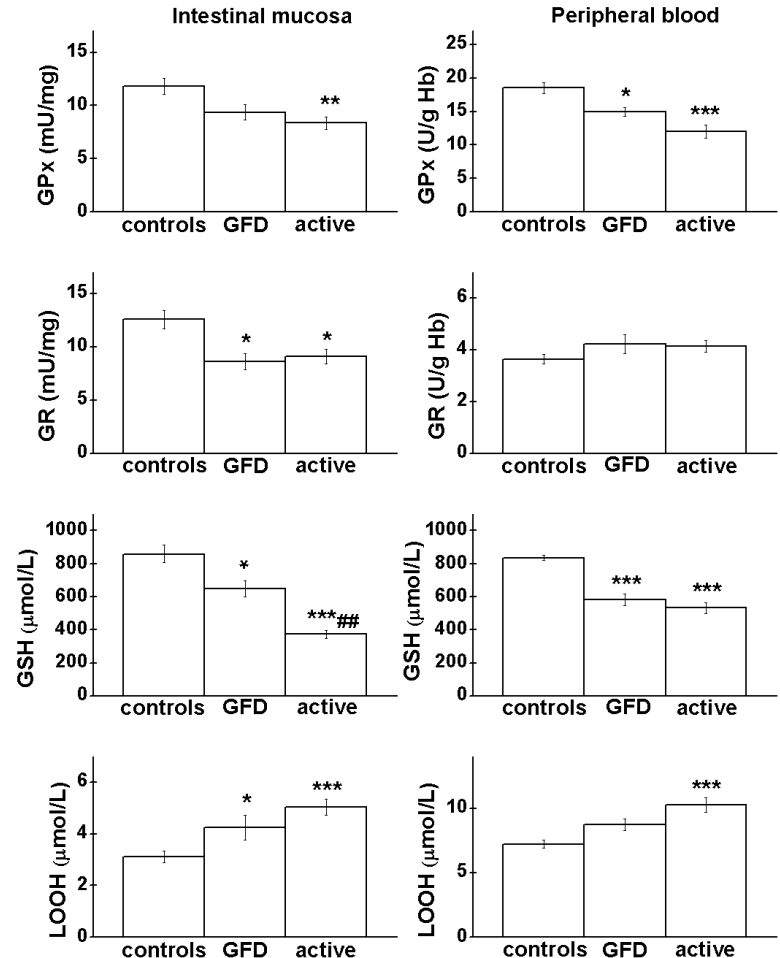

Figure 1. The activities of glutathione peroxidase (GPx) and glutathione reductase (GR) and the concentrations of glutathione (GSH) and lipid hydroperoxides (LOOH) in small intestinal mucosa and peripheral blood of control subjects, patients on gluten-free diet (GFD) and patients with the active form of the celiac disease. *** $P<0.001, * * P<0.01$, $* P<0.05$ significantly different from control subjects. \#\# $P<0.01$ significantly different from the GFD group. 
The GR activity varied significantly in the intestinal mucosa $(\mathrm{F}=6.77, P<0.01)$, but not in the erythrocytes $(\mathrm{F}=1.86, P>0.05)$. In comparison to the control group the GR activity decreased in the mucosa for about $30 \%$ in active and GFD groups $(P<0.05)$.

A significant variance among the analyzed groups was found for the GSH concentration in the intestinal mucosa $(\mathrm{F}=27.19, \mathrm{P}<0.001)$ and peripheral blood $(\mathrm{F}=45.77, \mathrm{P}<0.001)$. In the mucosa of the active group, the GSH level was less than 50 $\%$ of the control value $(\mathrm{P}<0.001)$, while in the GFD group the decrease in the GSH concentration was more restrained (about $25 \%, P<0.05$ ). The GSH concentration was also significantly reduced in the blood of active and GFD groups $(\sim 30 \%, P<0.001)$.

The levels of $\mathrm{LOOH}$ varied significantly in the intestinal mucosa $(\mathrm{F}=11.30, P<0.001)$ and in the plasma $(\mathrm{F}=14.69, P<0.001)$. The level of $\mathrm{LOOH}$ in the intestinal mucosa of celiac patients increased by $40 \%(P<0.05)$ in the GFD and over $60 \%(P<0.001)$ in the active group in comparison to the control subjects. The increase in the $\mathrm{LOOH}$ level was also found in the patients' plasma, but it was significant only in the active group (over $40 \%, P<0.001$ ).

The correlations among the analyzed parameters are represented in Fig. 2. The GPx activity significantly correlated with the GSH concentration in small intestinal mucosa, as well as in blood. Significant negative correlations were found between GSH and $\mathrm{LOOH}$ concentrations both in intestinal mucosa and peripheral blood, while the GR activity negatively correlated with the $\mathrm{LOOH}$ concentration in the intestinal mucosa only. We also found significant positive correlations of all analyzed parameters in small intestinal mucosa and blood, with the exception of the GR activity (Fig. 3).
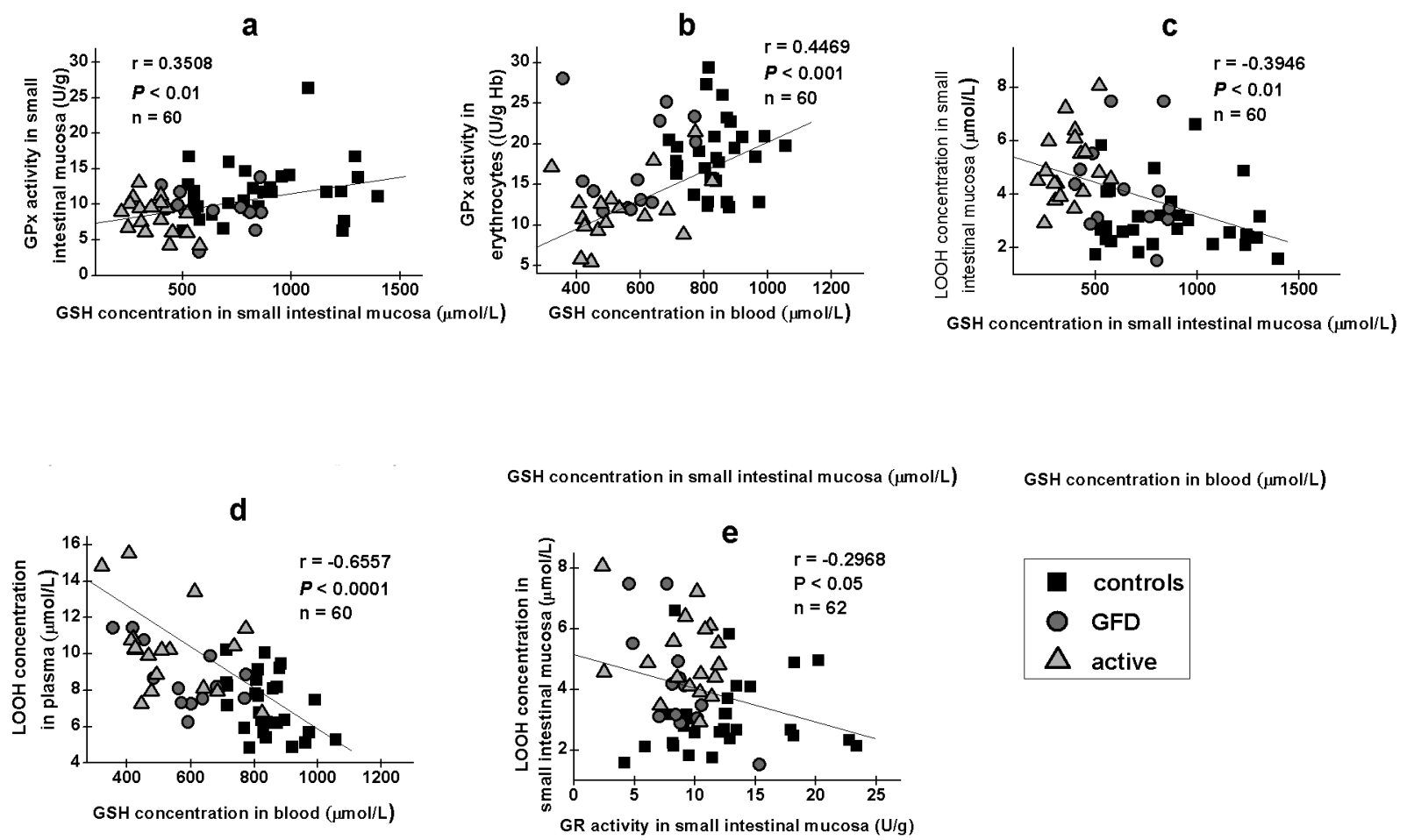

GSH concentration in small intestinal mucosa ( $\mu \mathrm{mol} / \mathrm{L})$

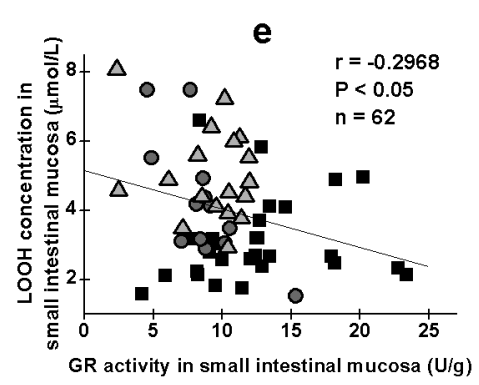

GSH concentration in blood ( $\mu \mathrm{mol} / \mathrm{L})$

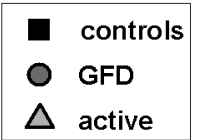

Figure 2. Data plot and coefficients of Pearson's product moment correlation $r$ between the GSH concentration and the GPx activitiy in small intestinal mucosa (a) and peripheral blood (b), the GSH concentration and the LOOH concentration in small intestinal mucosa (c) and peripheral blood (d), and the GR activity and the LOOH concentration in small intestinal mucosa (e) of control subjects, patients on gluten-free diet (GFD) and patients with the active form of the celiac disease. 

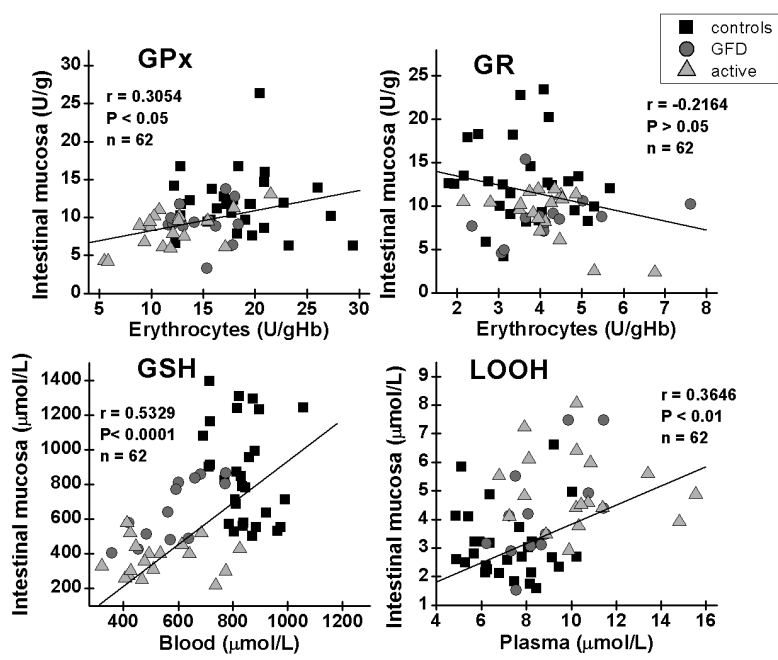

Figure 3. Data plot and coefficients of Pearson's product moment correlation $\mathrm{r}$ among the GPx activitiy, GR activity, GSH concentration and $\mathrm{LOOH}$ concentration in small intestinal mucosa and peripheral blood of control subjects, patients on gluten-free diet (GFD) and patients with the active form of the celiac disease.

\section{DISCUSSION}

The intestinal mucosa is continually subjected to the influence of oxidants, mutagens and carcinogens from diet, as well as to endogenous ROS. Several defense mechanisms are implied in maintaining the cell integrity and tissue homeostasis: the intestine is able to retain high concentrations of antioxidants (GSH, vitamins $\mathrm{E}$ and $\mathrm{C}$ ) and to up-regulate $\mathrm{AO}$ enzymes, while apoptosis is induced in spent or damaged enterocytes (Aw 1999). It was shown that xantine-oxidase (XO) is activated in the enterocytes of celiac patients, leading to the overproduction of free radicals and ROS (Boda et al. 1999). These pro-oxidant processes may cause further damage to the intestinal mucosa through free radical chain reaction in the LPO and elevated $\mathrm{LOOH}$ level, which can have far-reaching effects on the intestinal metabolic homeostasis. In our study, significantly increased concentrations of $\mathrm{LOOH}$ were found in the intestinal mucosa of patients with the active form of the disease, and even in patients on GFD. $\mathrm{LOOH}$ were also elevated in the plasma of celiac patients in the active group. Our results are in accordance with the findings of Rivabene et al. (1999) who reported an increased level of $\mathrm{LOOH}$ and a decreased level of GSH provoked by wheat gliadin in an in vitro study. The increased LPO of plasma chylomicrons and low-density lipoproteins of a celiac patient has also been reported (Lavy et al. 1993). It was shown that a high $\mathrm{LOOH}$ level provokes single- and double-strand DNA breaks as well as the oxidative damage of cell membranes (Wijeratne and Cuppett 2006). Subtoxic concentrations of LOOH can cause an oxidative shift in the cellular redox status that is sufficient for an enhanced mitogenic response, while under a severe oxidative stress cells die by apoptosis or necrosis (Gotoh et al. 2002, Aw 1999).

The GSH redox cycle is the principal mechanism of detoxifying $\mathrm{LOOH}$ in the intestine (Aw 2005). High levels of cell GSH are preserved by de novo synthesis, regeneration from GSSG, and in several cell types, including enterocytes, by an import via $\mathrm{Na}^{+}$-dependent transport system (Mårtensson et al. 1990). In our study, a significant decrease of the GSH concentration is found in the intestinal mucosa of celiac patients with the active form of the celiac diseas, and even in patients on the GFD regime the GSH level was $25 \%$ less than in control subjects. The GSH concentration is also significantly reduced in the peripheral blood of both active and GFD patient groups. The GSH depletion is followed by a decrease of the GPx and GR activities. A reduced GPx activity has been found in biopsies and erythrocytes taken from celiac patients with severe villous atrophy (Ståhlberg et al. 1988, Ståhlberg and Hietanen 1991). Several in vitro studies have reported pro-oxidative effects of gliadin in human intestinal cell cultures (Dolfini 2002, Dolfini 2005). Rivabene et al. (1999) demonstrated that the antiproliferative effect of gliadin is associated with pro-oxidative changes, such as elevated $\mathrm{LOOH}$ level, reduced GSH level and progressive disappearance of sulfhydryl groups in proteins. The magnitude of these changes 
correlated with the basal redox state of the cells, mainly the GSH content, suggesting that higher GSH levels could lessen cell susceptibility to gliadin. In another in vitro study, gliadin provoked a reduction in the GSH content and a gliadin concentration-related decrease in the activity of GR, GPx and GSH-S-transferase (Elli et al. 2003).

In our study the increased $\mathrm{LOOH}$ concentrations correlated with the reduction of the GSH content in the intestinal mucosa and peripheral blood. We also found a significant positive correlation between the GSH concentration and the GPx activity in both tissues, while the GR activity in the mucosa inversely correlated with the LOOH concentration. Since it was shown that GPx and GR are not influenced by a high LOOH concentration (Reddy and Tappel 1974, Vilas et al. 1976), the decreased activities of these enzymes might be a consequence of the GSH depletion. Our results are consistent with the findings of Aw (1998) who demonstrated that the extent of LOOH catabolism and the kinetics of GPx and GR depend mainly on the availability of cell reductants (GSH and NADPH). Moreover, as Gpx is a selenium-dependent enzyme, a low Se level can also influence its activity. Selenium deficiency has already been reported in celiac patients (Stazi and Trinti 2010, Yuce et al. 2004). Previous studies have also shown a strong correlation between the Gpx activity and the Se level in blood, especially when the Se concentration is low $(<80 \mu \mathrm{g} / \mathrm{L})$ (McKenzie et al. 1978, Lloyd et al. 1989).

Since sufficient GSH is essential for normal intestinal degradation of $\mathrm{LOOH}$ from diet, the reduced GSH level found in our study might promote their luminal retention and lymphatic transport. The LOOH challenge may provoke perturbation in the normal intestinal cell proliferation, differentiation and apoptotic responses, contributing to the increased risk of malignancy in untreated celiac patients.

Besides the GSH redox cycle, thioredoxin and a family of recently discovered peroxiredoxins are potent detoxifiers of peroxides. Thioredoxin and peroxiredoxins, by using redox-active cysteines rather than selenium, reduce hydrogen peroxide and organic peroxides. The active form of thioredoxin is recovered by selenoprotein thioredoxin reductase (Forman et al. 2002, 2004), while oxidized peroxiredoxins are reduced by thiols such as GSH, or ascorbic acid (Monteiro et al. 2007, Jönsson and Lowther 2007). Thioredoxin and peroxiredoxins have not been investigated in celiac disease yet. Still, the general absorptive dysfunction of small intestine in patients with the celiac disease could possibly diminish their peroxide detoxifying function via reduced level of selenium and GSH, as in a case of GPx recorded in this work.

Our results demonstrate that the oxidative stress is implicated in the pathology of celiac disease. The antioxidant capacity of celiac patients with the active form of the disease is significantly reduced by the GSH depletion and decreased activities of GSH-related enzymes in intestinal mucosa and peripheral blood. In patients on GFD, the prooxidant/antioxidant balance is greatly recovered, but even in these patients the GSH levels in mucosa and peripheral blood, the GR activity in mucosa and the GPx activity in erythrocytes remain lowered, while LOOH are still elevated in mucosa. Interestingly, the GSH concentration in intestinal mucosa increased significantly in GFD patients when compared to the active group, while in blood it persists at very low levels. This could be explained by the fact that after the healing of intestinal mucosa and the regaining of its absorptive function, enterocytes are able to take dietary GSH from the intestinal lumen, which is an important source of intracellular GSH (Lash 1986, Mårtensson et al. 1990), while the rate of the GSH synthesis in the intestinal epithelial cells is relatively low (Williams and Aw 1994). The restoration of the GSH content in erythrocytes seems to be delayed and more complex, involving the transport of amino acids into cells and de novo intracellular synthesis. Cysteine is considered to be a rate-limiting amino acid for the GSH synthesis. It has been demonstrated 
that the transport of cystine (an oxidized form of cysteine) is induced in erythrocytes under oxidative stress (Ohtsuka et al. 1988).

The pattern of the observed alterations in GSH redox cycle in the intestinal mucosa and peripheral blood is very similar, suggesting that these changes are of systemic character. Rivabene et al. (1999) proposed that a diffuse inflammatory process that is characteristic for the active phase of the celiac disease might represent a basis for the systemic disturbance of pro-oxidant/antioxidant balance in an organism. Significant positive correlations of all analyzed parameters except for the GR activity in the two tissues, observed in our study, strongly support this opinion.

Our results clearly demonstrate that the GSH concentration is severely reduced in small intestinal mucosa and blood of celiac patients, even after several years of GFD. It was shown that the oral administration of GSH increases its levels in small and large intestinal mucosa of mice and protects these tissues from cell degeneration induced by L-buthionine SR-sulfoximine (BSO), a specific inhibitor of the GSH synthesis (Marrtensson et al. 1990). Considering a systemic decrease of the GSH level and overall AO capacity in celiac patients, the oral administration of GSH and a diet enriched by natural antioxidants and appropriate dietary supplements could be important for full healing of these patients. In addition, we suggest that nutritional evaluation confirming a 'replenishing of reserves' should be performed at the diagnosis level and at least once a year to address damage control in the patients.

\section{ACKNOWLEDGMENTS}

This work received the financial support of the Ministry of Education and Science of the Republic of Serbia (Grants III 41027 and OI 173041).

\section{RESUMO}

A doença celíaca é uma desordem gastrointestinal causada pelo glúten proveniente do trigo, centeio ou cevada. Em pessoas geneticamente predispostas, o glúten induz uma inflamação imune da mucosa do intestino delgado. As lesões histológicas incluem linfocitose intraepitelial, hipertrofia de criptas e atrofia vilosa, resultando em malabsorção de microe macronutrientes. O único tratamento para os pacientes celíacos é a restrição permanente de glúten na dieta (GFD). Espécies reativas de oxigênio (ROS) e o estresse oxidativo estão fortemente associados à doença celíaca. O glutatião (GSH) é o principal detoxificante de ROS endógeno ou exógeno no intestino. Para explicar o papel do ciclo redox do glutatião nos pacientes celíacos, nós examinamos as atividades das enzimas GSH-relacionadas e anti-oxidantes (AO) glutatião peroxidase (GPx) e glutatião redutase (GR), assim como a concentração de GHS em biópsias do intestino delgado e sangue periférico de crianças afetadas pela doença celíaca. A concentração dos hidroperóxidos lipídicos (LOOH) como marcadores do dano oxidativo foi medida em várias amostras. Os resultados mostram claramente a mal função significante do ciclo redox do GSH com uma diminuição concomitante da capacidade de regenerar GSH e detoxificar $\mathrm{LOOH}$ nos pacientes celíacos, mesmo após vários anos de GFD. A administração oral de GSH e uma dieta rica em anti-oxidantes naturais, assim como de suplementos apropriados na dieta, poderiam ser de grande benefício aos pacientes.

Palavras-chave: enzimas anti-oxidantes, doença celíaca, glutatião, peroxidação de lipídios.

\section{REFERENCES}

AW TY. 1998. Determinants of intestinal detoxication of lipid hydroperoxides. Free Radic Res 128: 637-646.

AW TY. 1999. Molecular and cellular responses to oxidative stress and changes in oxidation-reduction imbalance in the intestine. Am J Clin Nutr 70: 557-565.

Aw TY. 2005. Intestinal glutathione: determinant of mucosal peroxide transport, metabolism, and oxidative susceptibility. Toxicol Appl Pharmacol 204: 320-328.

BODA M, NÉMETH I AND BODA D. 1999. The caffeine metabolic ratio as an index of xanthine oxidase activity in clinically active and silent celiac patients. J Pediatr Gastroenterol Nutr 29: 546-550.

DEWAR DH AND CIClitiRA PJ. 2005. Clinical features and diagnosis of celiac disease. Gastroenterology 128: 19-24. 
DOLFINI E ET AL. 2002. In vitro cytotoxic effect of bread wheat gliadin on the LoVo human adenocarcinoma cell line. Toxicol In Vitro 16: 331-337.

DoLFINI E ET AL. 2005. Damaging effects of gliadin on threedimensional cell culture model. World J Gastroenterol 11: 5973-5977.

Dugas B, Dugas N, Conti M, Calenda A, Pino P, Thomas Y, MAZIER D AND VouldouKIS I. 2003. Wheat gliadin promotes the interleukin-4-induced IgE production by normal human peripheral mononuclear cells through a redox-dependent mechanism. Cytokine 21: 270-280.

Elli L, Dolfini E AND BARdella MT. 2003. Gliadin cytotoxicity and in vitro cell cultures. Toxicol Lett 146: 1-8.

ESTEVE M ET AL. 2006. Spectrum of gluten-sensitive enteropathy in first-degree relatives of patients with coeliac disease: clinical relevance of lymphocytic enteritis. Gut 55: 1739-1745.

FARRELl RJ AND Kelly CP. 2002. Celiac sprue. N Engl J Med 346: $180-188$.

FASANO A AND CATASSI C. 2005. Coeliac disease in children. Best Pract Res Clin Gastroenterol 19: 467-478.

FORMAN HJ, FUKUTO J AND TORRES M. 2004. Redox signaling: thiol chemistry defines which reactive oxygen and nitrogen species can act as second messengers. Am J Physiol Cell Physiol 287: 246-256.

FORMAN HJ, TORRES M AND FUKUTO J. 2002. Redox signaling. Mol Cell Biochem 234/235: 49-62.

GotoH Y, NODA T, IWAKIRI R, FUJIMOTO K, RHOADS CA AND AW TY. 2002. Lipid peroxide-induced redox imbalance differentially mediates $\mathrm{CaCo}-2$ cell proliferation and growth arrest. Cell Prolif 35: 221-235.

Green PH, Fleischauer AT, Bhagat G, Goyal R, Jabri B AND NEUGUT AI. 2003. Risk of malignancy in patients with celiac disease. Am J Med 115: 191-195.

HwANG C, Sinskey AJ AND Lodish HF. 1992. Oxidized redox state of glutathione in the endoplasmic reticulum. Science 257: 1496-1502.

JÖNSSON TJ AND LOWTHER WT. 2007. The peroxiredoxin repair proteins. Subcell biochem 44: 115-141.

Kosower NS AND Kosower EM. 1978. The glutathione status of cells. Int Rev Cytol 54: 109-160.

LASH LH, HAGEN TM AND JONES DP. 1986. Exogenous glutathione protects intestinal epithelial cells from oxidative injury. Proc Natl Acad Sci USA 83: 4641-4645.

LAVY A, BEN AMOTZ A AND AVIRAM M. 1993. Increased susceptibility to undergo lipid peroxidation of chylomicrons and low-density lipoprotein in celiac disease. Ann Nutr Metab 37: 68-74.

LEGRAND TS AND AW TY. 2001. Intestinal absorption of lipid hydroperoxides. In: MANSBACH C ET AL. (Eds), Intestinal lipid metabolism, New York: Plenum Publishing Corporation, New York, USA, p. 351-366.
Liu D, Bao F, Prough DS And Dewitt DS. 2005. Peroxynitrite generated at the level produced by spinal cord injury induces peroxidation of membrane phospholipids in normal rat cord: reduction by a metalloporphyrin. $\mathrm{J}$ Neurotrauma 22: 1123-1133.

Lloyd B, Robson E, SMITH I AND CLAYTON BE. 1989. Blood selenium concentrations and glutathione peroxidase activity. Arch Dis Child 64: 352-356.

Maiuri MC, De Stefano D, Mele G, Iovine B, BeviLACQUA MA, GRECO L, AURICCHIO S AND CARNUCCIO R. 2003. Gliadin increases iNOS gene expression in interferongamma-stimulated RAW 264.7 cells through a mechanism involving NF-kappa B. Naunyn Schmiedebergs Arch Pharmacol 368: 63-71.

MÅrtensson J, Jain A AND Meister A. 1990. Glutathione is required for intestinal function. Proc Natl Acad Sci USA 87: $1715-1719$

Masella R, Di Benedetto R, VARI R, Filesi C AND GIOVANNINI C. 2005. Novel mechanisms of natural antioxidant compounds in biological systems: involvement of glutathione and glutathione-related enzymes. J Nutr Biochem 16: 577-586.

MCKENZIE RL, REA HM, THOMSON CD AND ROBINSON MF. 1978. Selenium concentration and glutathione peroxidase activity in blood of New Zealand infants and children. Am J Clin Nutr 31: 1413-1418.

Monteiro G, Horta BB, Pimenta DC, Augusto O And NeTTO LE. 2007. Reduction of 1-Cys peroxiredoxins by ascorbate changes the thiol-specific antioxidant paradigm, revealing another function of vitamin C. Proc Natl Acad Sci USA 104: 4886-4891.

MURRAY JA. 1999. The widening spectrum of celiac disease. Am J Clin Nutr 69: 354-365.

OHTSUKA Y, Kondo T AND KAWAKAMI Y. 1988. Oxidative stresses induced the cystine transport activity in human erythrocytes. Biochem Biophys Res Commun 155: 160-166.

REDDY K AND TAPPEL AL. 1974. Effect of dietary selenium and autoxidized lipids on the glutathione peroxidase system of gastrointestinal tract and other tissues in the rat. J Nutr 104: 1069-1078.

Rivabene R, MANCINI E AND DE VINCENZI M. 1999. In vitro cytotoxic effect of wheat gliadin-derived peptides on the Caco-2 intestinal cell line is associated with intracellular oxidative imbalance: implications for coeliac disease. Biochim Biophys Acta 1453: 152-160.

RYAN BM AND KELLEHER D. 2000. Refractory celiac disease. Gastroenterology 119: 243-251.

SPITELLER G. 2007. The important role of lipid peroxidation processes in aging and age dependent diseases. Mol Biotechnol 37: 5-12.

STÅHLBERG MR AND HietANEN E. 1991. Glutathione and glutathione-metabolizing enzymes in the erythrocytes of healthy children and in children with insulin-dependent diabetes mellitus, juvenile rheumatoid arthritis, coeliac disease and acute lymphoblastic leukaemia. Scand J Clin Lab Invest 51: 125-130. 
StÅHLberg MR, HietAnen E AND MÄKi M. 1988. Mucosal biotransformation rates in the small intestine of children. Gut 29: 1058-1063.

STAZI AV AND TRINTI B. 2010. Selenium status and overexpression of interleukin-15 in celiac disease and autoimmune thyroid diseases. Ann Ist Super Sanita 46: 389-399.

StoJiljković V, TOdorović A, PeJIĆ S, KASAPOVIĆ J, SAICIĆ ZS, RADlović N AND PAJOVIĆ SB. 2009. Antioxidant status and lipid peroxidation in small intestinal mucosa of children with celiac disease. Clin Biochem 42: 1431-1437.

StoJiljković V, TOdorović A, RAdlović N, PEJIĆ S, Mladenović M, Kasapović J And Pajović SB. 2007. Antioxidant enzymes, glutathione and lipid peroxidation in peripheral blood of children affected by coeliac disease. Ann Clin Biochem 44: 537-543.
VILAS NN, BELL RR AND DRAPER HH. 1976. Influence of dietary peroxides, selenium and vitamin $\mathrm{E}$ on glutathione peroxidase of the gastrointestinal tract. J Nutr 106: 589-596.

WALKER-SMITH JA. 1990. Revised criteria for diagnosis of coeliac disease. Report of Working Group of European Society of Paediatric Gastroenterology and Nutrition. Arch Dis Child 65: 909-911.

WiJERATNE SS AND CUPPETT SL. 2006. Lipid hydroperoxide induced oxidative stress damage and antioxidant enzyme response in Caco-2 human colon cells. J Agric Food Chem 54: 4476-4481.

WiLliams AD AND Aw TY. 1994. Glutathione (GSH) supply for lipid hydroperoxide metabolism in intestinal epithelial cells. Gastroenterology 106: 1054.

Yuce A, Demir H, Temizel IN AND KocaK N. 2004. Serum carnitine and selenium levels in children with celiac disease. Indian J Gastroenterol 23: 87-88. 